http://government.ru/media/files/ceFXleNUqOU.pdf, свободный (дата обращения: 06.02.2017). - $14 \mathrm{c}$.

2. Стратегия научно-технологического развития Российской Федерации (утверждена Указом Президента РФ от 1 декабря 2016 года №642). [Электронный pecypc]. Режим доступа: http://docs.cntd.ru/document/420384257, свободный (дата обращения: 06.02.2017). - 24 с.

3. Стратегия развития федерального государственного бюджетного образовательного учреждения высшего образования «Российский государственный аграрный университет - МСХА имени К.А. Тимирязева» на 2016-2030 гг. (утверждена ректором РГАУ-МСХА имени К.А. Тимирязева от 30 июня 2016 г.). [Электронный pecypc]. Режим доступа: http://www.timacad.ru/about/data/docs/strategiya-2016-2030.pdf, свободный (дата обращения 06.02.2017 г.). - 124 с.

\title{
Выявление и формирование уровня готовности студентов к выполнению нормативов комплекса «Готов к труду и обороне» (на примере групп общефизической подготовки ТИ (ф) СВФУ)
}

\author{
Мороз А.А., студентка, \\ E-mail: anna moroz1995@mail.ru \\ Добрынина А.И., студентка, \\ E-mail: alena.sweet91@mail.ru \\ Технический институт (филиал) \\ Северо-Восточного федерального университета, г. Нерюнгри
}

Научный руководитель: к.n.н., доцент Прокопенко Л.А.

Указ Президента Российской Федерации «О Всероссийском физкультурноспортивном комплексе «Готов к труду и обороне» (ГТО) № 172 от 24.03.2014 г. положил начало возрождению российских традиций здоровьесбережения нации. Возрождение и внедрение Всероссийского физкультурно-спортивного комплекса ГТО является общенациональной задачей создания эффективной системы физического воспитания, направленной на развитие человеческого потенциала и укрепление здоровья населения.

Исследование физической активности студентов ТИ (ф) СВФУ в свободное время в октябре 2015 г. показало, что большинство опрошенных студентов не занимаются физкультурой и спортом во внеучебное время, особенно во время сессии и каникул, а также в утренние часы [1]. Такой результат настораживает, тем более в период внедрения комплекса ГТО, предусматривающего высокие требования к уровню развития физических качеств.

Для целенаправленной физической подготовки к выполнению нормативов комплекса ГТО одних только учебно-тренировочных занятий недостаточно, поэтому нами был разработан проект, предусматривающий создание положительной мотивации и повышение уровня готовности студентов к выполнению нормативов комплекса ГТО с упором на самостоятельные занятия.

Цель работы - экспериментально проверить эффективность проекта по выявлению и формированию готовности студентов к выполнению нормативов 
комплекса «Готов к труду и обороне» (на примере групп общефизической подготовки ТИ (ф) СВФУ).

Нами использованы следующие методы исследования: анализ литературы, анкетирование информированности студентов о комплексе ГТО, педагогический эксперимент, математическая обработка данных.

Исследования проводились на базе ТИ (ф) СВФУ в 2016 г. в 3 этапа: подготовительный - февраль, основной - февраль-апрель, заключительный - май. В педагогическом эксперименте приняли участие студенты дневного отделения 1-2 курсов в количестве 20 человек (9 юношей и 11 девушек), занимающиеся по программе «Общая физическая подготовка». В организованных мероприятиях принимали участие все желающие студенты 1-4 курсов.

На подготовительном этапе мы провели анкетирование студентов «Что ты знаешь о комплексе ГТО?». В целом их информированность составила 44\%.

Также на этом этапе были проведены испытания по нормативам комплекса ГТО для исходных данных (табл. 1-2):

Таблица 1

Исходные показатели юношей при выполнении нормативов комплекса ГТО (в \%)

\begin{tabular}{|c|l|c|c|c|c|c|}
\hline № & \multicolumn{1}{|c|}{ Показатели } & Бронза & Серебро & Золото & $\begin{array}{c}\text { Выполнили } \\
\text { норматив }\end{array}$ & $\begin{array}{c}\text { Не } \\
\text { выполнили } \\
\text { норматив }\end{array}$ \\
\hline 1. & $\begin{array}{l}\text { Прыжок в длину с места } \\
\text { толчком двумя ногами }\end{array}$ & 11,1 & 11,1 & 11,1 & 33,3 & 66,7 \\
\hline 2. & $\begin{array}{l}\text { Подтягивание на } \\
\text { высокой перекладине }\end{array}$ & 11,1 & 11,1 & 11,1 & 33,3 & 66,7 \\
\hline 3. & $\begin{array}{l}\text { Наклон вперед из } \\
\text { положения стоя с } \\
\begin{array}{l}\text { прямыми ногами на } \\
\text { гимнастической скамье }\end{array}\end{array}$ & - & 33,3 & 33,3 & 66,6 & 33,4 \\
\hline
\end{tabular}

Анализируя результаты у юношей, можно сказать, что исходные данные группы по всем трем показателям низкие. Это говорит о том, что студенты поступают в институт с низким уровнем физической подготовленности. Полагаем, в школе уделяется недостаточное внимание этим показателям.

Таблица 2

Исходные показатели девушек при выполнении нормативов комплекса ГТО (в \%)

\begin{tabular}{|l|l|c|c|c|c|c|}
\hline № & \multicolumn{1}{|c|}{ Показатели } & Бронза & Серебро & Золото & $\begin{array}{c}\text { Выполнили } \\
\text { норматив }\end{array}$ & $\begin{array}{c}\text { Не } \\
\text { выполнили } \\
\text { норматив }\end{array}$ \\
\hline 1. & $\begin{array}{l}\text { Прыжок в длину с места } \\
\text { толчком двумя ногами }\end{array}$ & 18,2 & 9,1 & - & 27,3 & 72,7 \\
\hline 2. & $\begin{array}{l}\text { Поднимание туловища } \\
\text { из положения лежа на } \\
\text { спине }\end{array}$ & - & 36,4 & 27,3 & 63,6 & 36,4 \\
\hline
\end{tabular}




\begin{tabular}{|l|l|c|c|c|c|c|}
\hline 3. & $\begin{array}{l}\text { Наклон вперед из } \\
\text { положения стоя с } \\
\text { прямыми ногами на } \\
\text { гимнастической скамье }\end{array}$ & 27,2 & 36,4 & 36,4 & 100 & - \\
\hline
\end{tabular}

Из таблицы видно, что начальные показатели по группе девушек в прыжках в длину тоже очень низкие. В упражнении на силу большинство девушек имеют хороший исходный уровень, и качественный показатель отмечается на уровне серебряного и золотого знаков отличия. Норматив на гибкость не является для них проблемой и с ним успешно справилась вся группа, имея хорошие качественные показатели. Следовательно, показателю по прыжкам в длину с места нужно больше уделять внимания, начиная со школы.

Для повышения результатов уровня физической подготовленности нами были разработаны методические рекомендации в виде буклетов «Сильнее, дальше, гибче!» (рис. 1-2), предусматривающие, самостоятельные занятия в спорткомплексе института и домашних условиях.
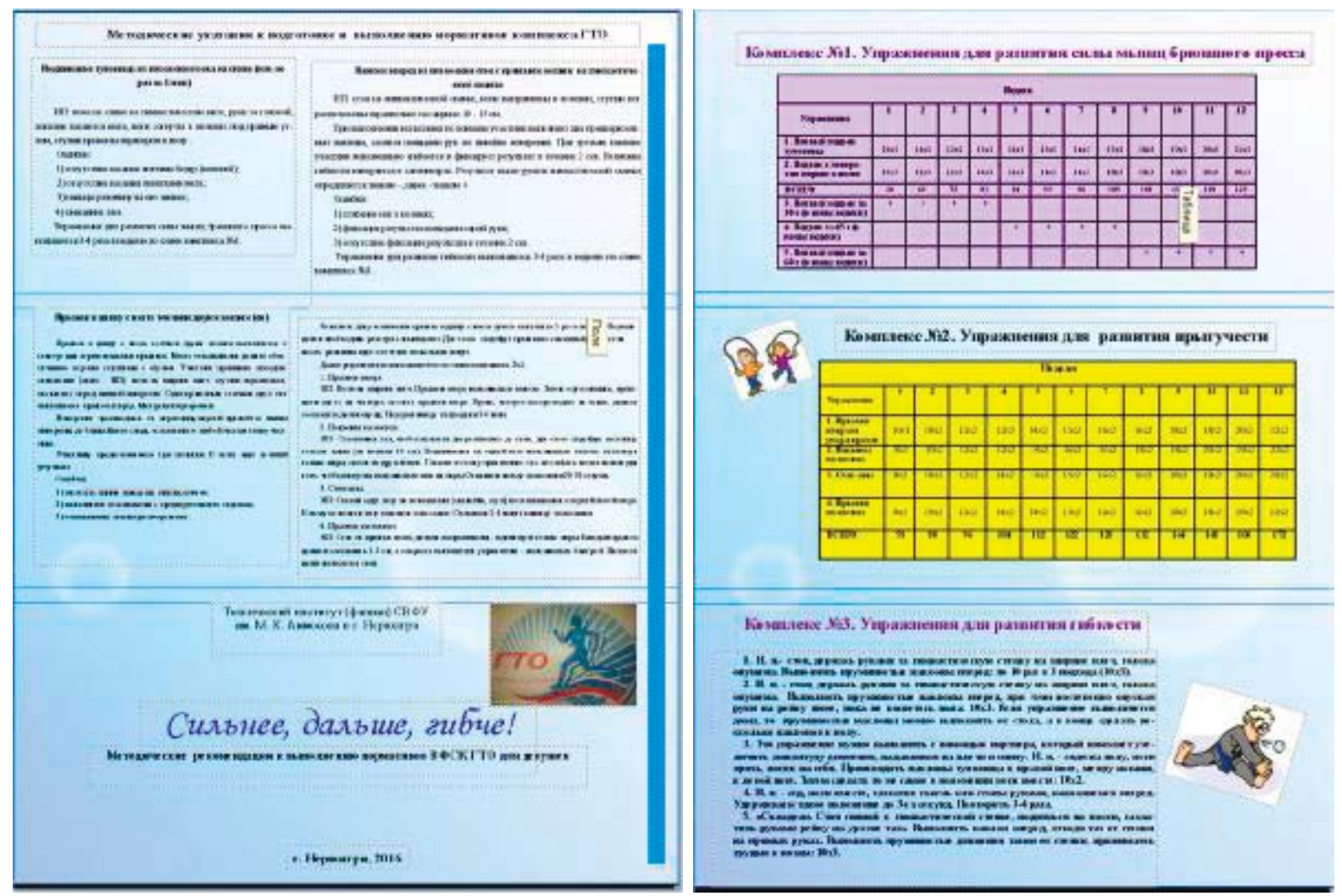

Рис. 1. Буклет «Сильнее, дальше, гибче» для девушек 

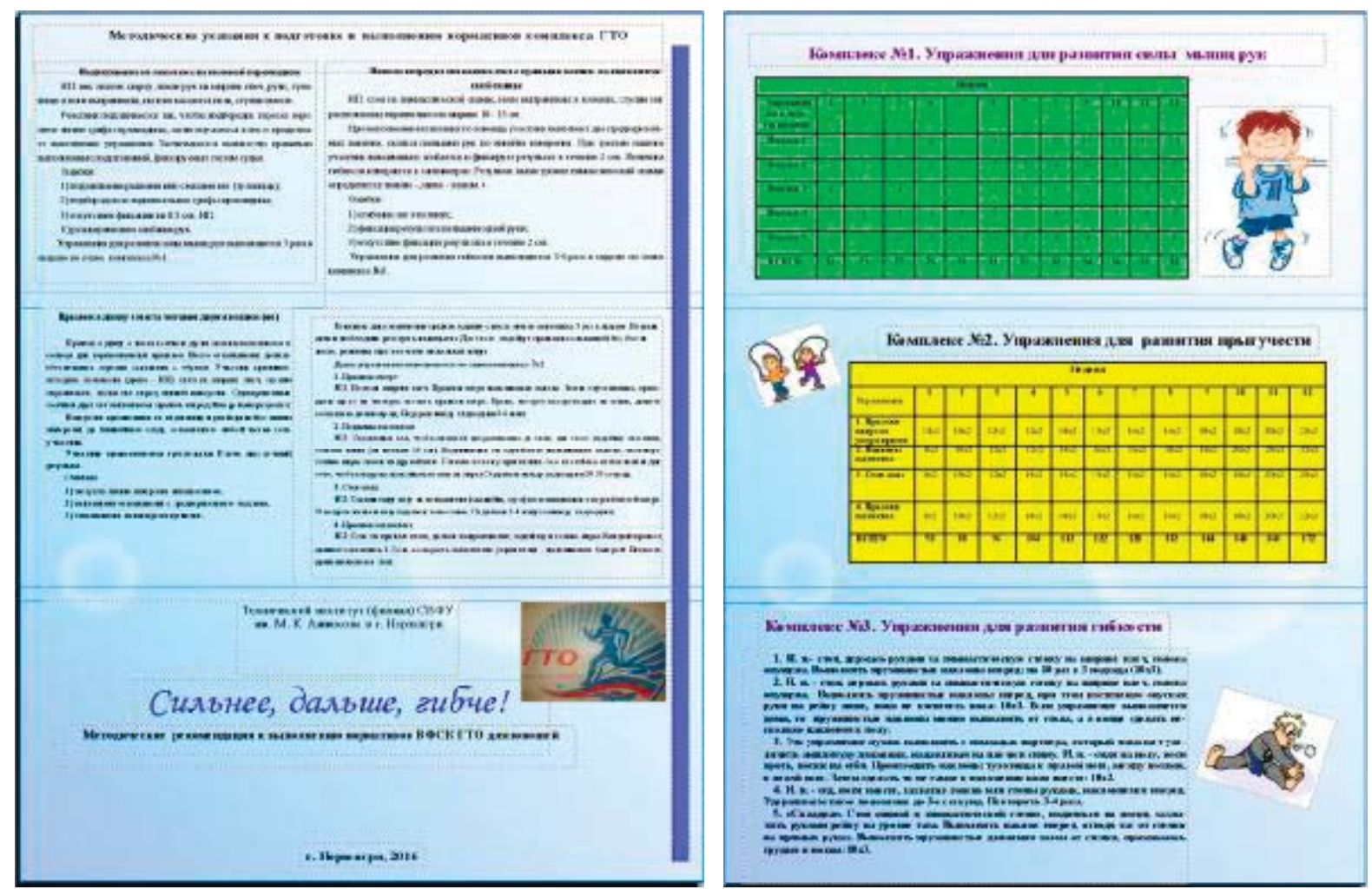

Рис. 2. Буклет «Сильнее, дальше, гибче» для юношей

В буклетах включено описание техники выполнения упражнений, возможные ошибки выполнения и комплексы упражнений для индивидуальных тренировок таких нормативов, как подтягивание из виса на высокой перекладине для юношей, поднимание туловища из положения лежа на спине (кол-во раз за 1 мин) для девушек, наклон вперед из положения стоя с прямыми ногами на скамье, прыжок в длину с места толчком двумя ногами для юношей и девушек. Выбор упражнений обусловлен необходимостью проведения занятий в спортзале и в домашних условиях в зимний период времени в условиях Севера. Программы занятий с постепенным повышением нагрузки разработаны на 12 недель (3 месяца) и тренировками по 3-4 раза в неделю.

На основном этапе в целях формирования положительной мотивации студентов были проведены следующие мероприятия: семинар «Организация комплекса ГТО», конкурс плакатов «Кто выполняет комплекс ГТО - тот богат здоровьем, умом и телом», Тематическая встреча «Значкисты ГТО вчера и сегодня». По итогам конкурса плакатов была выбрана эмблемы проекта (рис. 3).

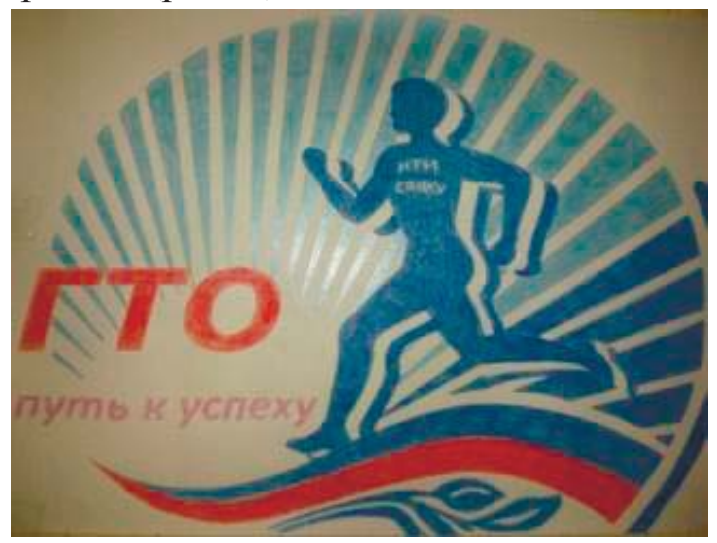

Рис. З. Эмблема проекта 
Основной этап включил проведение педагогического эксперимента. Каждый участник получил буклет и имел возможность заниматься самостоятельно как на учебнотренировочных занятиях по физической культуре, так и дополнительно во внеучебное время.

На заключительном этапе были организованы соревнования по многоборью комплекса ГТО, включающие тренировочные упражнения.

Пройдя целенаправленную подготовку в вузе в течение одного семестра по разработанной программе, можно констатировать улучшение качественных и количественных показателей у юношей по всем трем упражнениям. Так, количество юношей, выполнивших прыжок в длину с места и подтягивания на знаки отличия, увеличилось на 22,2\% и достигло 55,5\%. В тесте на гибкость увеличение достигло 77,7\%. Особо здесь следует отметить качество показателей, сопровождающееся увеличением количества студентов, выполнивших нормативы по более высоким знакам отличия в тестах на силу и гибкость.

Также после прохождения специальной подготовки мы можем наблюдать заметное повышение количества девушек (90,9\%), справляющихся с нормативом на силу и качественное улучшение этого показателя. Больше половины студенток (63,6\%) выполнили норматив на золотой знак отличия. В тесте на гибкость также наблюдается качественное улучшение показателя. На серебряный знак вышли 54,5\% девушек, было $36,4 \%$, на золотой - 45,5\%, было - 36,4\%. В прыжках в длину с места наметилось повышение результативности, но пока незначительное. Данный норматив требует более длительной подготовки.

В конце 3-го этапа студентам было предложено повторно ответить на вопросы анкеты «Что ты знаешь о комплексе ГТО?». В результате 93\% опрошенных студентов ответили правильно на все вопросы. Проведенное тестирование показало повышение информированности студентов на $49 \%$.

Выводы. Разработанная и апробированная нами программа по формированию уровня готовности студентов в ТИ (ф) СВФУ к выполнению нормативов ВФСК ГТО дала положительные результаты и может быть рекомендована преподавателям физвоспитания для работы с контингентом студентов вуза, а также указывает на необходимость уделять больше внимания скоростно-силовым качествам.

\section{Список литературы:}

1. Прокопенко, Л.А. О самостоятельных занятиях физическими упражнениями студентов в ТИ (ф) СВФУ в преддверии внедрения в вузах ВФСК ГТО / Л.А. Прокопенко // Международный журнал прикладных и фундаментальных исследований. - 2016. - № 10. - С. 647-649. 